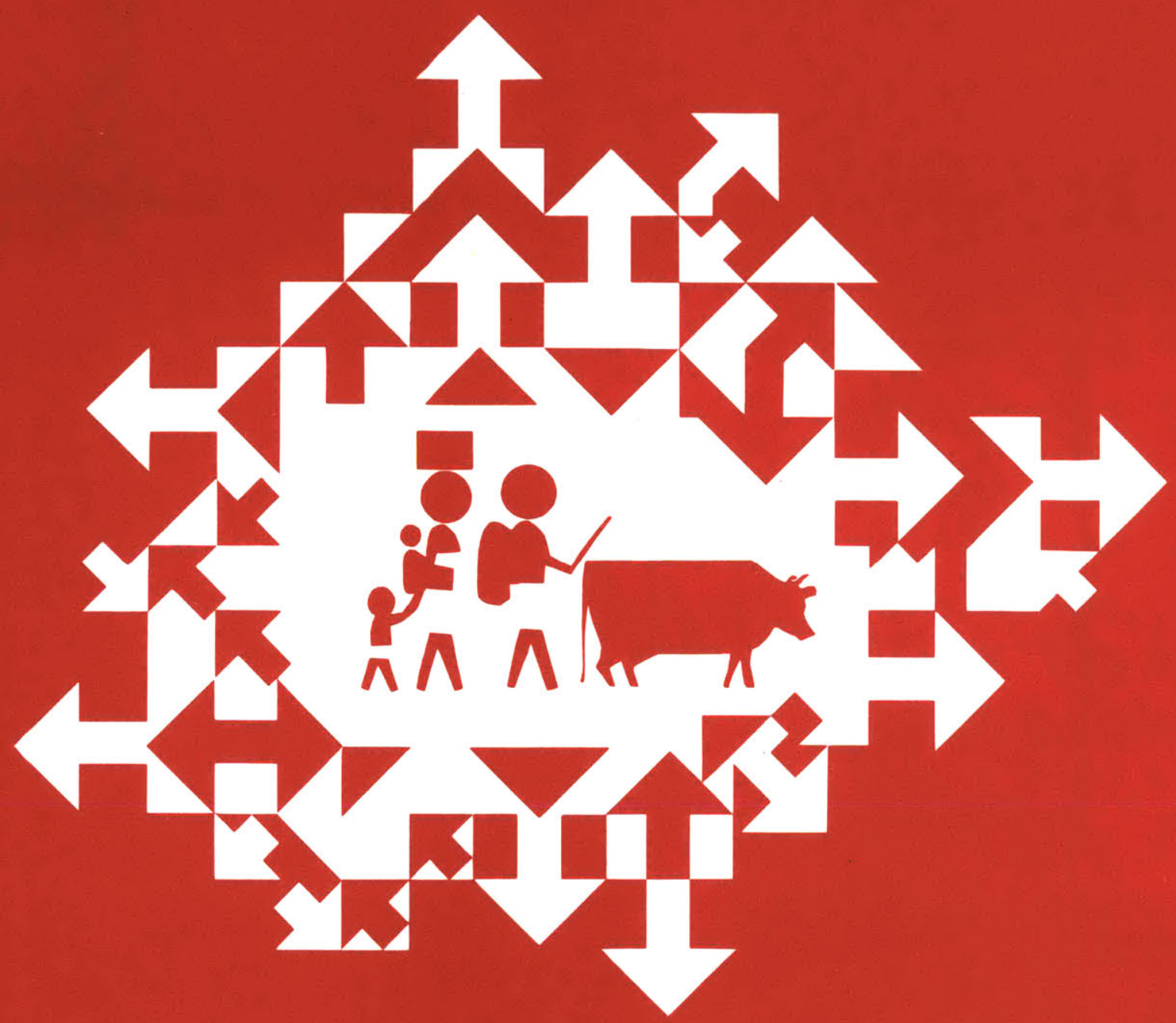

\title{
THE NEW MIGRATION IN THE MIDDLE EAST: A PROBLEM FOR WHOM?
}

\author{
Nazli Choucri
}

MIGRATION AND DEVELOPMENT STUDY GROUP

Center for International Studies

Massachusetts Institute of Technology

Cambridge, Massachusetts 02139 


\title{
MIGRATION AND DEVELOPMENT STUDY GROUP
}

\author{
Jagdish N. Bhagwati \\ Nazli Choucri \\ Wayne A. Cornelius \\ John R. Harris \\ Michael J. Piore \\ Rosemarie S. Rogers \\ Myron Weiner
}


$\mathrm{C} / 77-4$

THE NEW MIGRATION IN THE MIDDLE EAST:

A PROBLEM FOR WHOM?

Nazli Choucri

Massachusetts Institute of Technology

This paper is part of a research project undertaken within the context of the Technology Adaptation Program at MIT and is allowed to appear in the Migration and Development Series as a courtesy of the Technology Adaptation Program.

\footnotetext{
Migration and Development Study Group

Center for International Studies Massachusetts Institute of Technology

Cambridge, Massachusetts 02139
}

January 1977 



\section{CONTENTS}

$\underline{\text { Page }}$

I. Introduction 1

II. The New Migration in the Middle East 1

III. Egyptian Policies and Migration Patterns $\quad 5$

IV. Characteristic Features 9

V. Benefits to Egypt 12

VI. Costs to Egypt 15

$\begin{array}{ll}\text { VII. Migration and Development Planning } & 17\end{array}$

VIII. Toward a New Exchange: Some Policy Options 20

$\begin{array}{lr}\text { Notes } & 27\end{array}$ 



\section{Introduction}

Popular views of the Middle East tend to concentrate on the cultural homogeneity of the Arab states, their conflict with Israel, and the dispute over petroleum prices. Yet in recent years a new issue has emerged that may well dominate regional politics in the years to come, giving rise to problems with both economic and political ramifications. That issue is the increased migration of Egyptian workers -- skilled and unskilled -- to other Arab states and their importance to development programs and plans for social change. The volume of this migration and its consequences for regional politics are only dimly foreseen. Indeed, the very magnitude of that movement is itself in question, given the paucity of recorded data, conflicting reports, and political incentives for inaccurate representation. But there is every indication that it transcends narrow demographic concerns and will exert a powerful influence on relations among the Arab countries.

The purpose of this paper is to describe recent trends in migration throughout the Middle East, identify the major implications of this movement, and isolate critical policy issues for both Egypt and the other Arab states. We shall argue that international migration in the Middle East harbors political and economic effects that may be potentially explosive, and, in fact, current migration-related policies in the region could be counter-productive for all parties concerned. The burden of these arguments rests on the extent of migration, its composition, the differentials in wages and employment opportunities, savings and remittances of migrant workers, government policies for regulating the movement of manpower across territorial boundaries, and official expectations of the role of migration in development programs. Our purpose is to highlight the emergence of a new issue in Middle East politics, not to provide a detailed analysis of its many facets.

\section{The New Migration in the Middle East}

The petroleum crisis of October 1973 has drawn dramatic attention to the difference among the countries of the Middle East in terms of size and wealth. Indeed, the most populous countries are the poorest in natural 
resources, and the richest countries are smallest in population. In addition, vast differences exist in levei of technological development and manpower characteristics. The largest countries in population size are the most developed in terms of overall knowledge and skills. For the smaller but more wealthy countries, manpower availability is the single most important constraint on economic development. Over the years these differences have contributed to sharp patterns of migration across national boundaries and to the mobility of both skilled and unskilled labor. For all countries in the region -- donors as well as recipients -- the issue of labor migration is assuming unprecedented political proportions. Increasingly, the development programs of one country are affected by the population characteristics, migration patterns, and manpower policies of the other countries. And national policies designed to influence the movement of workers will invariably have regional implications.

To a large extent the Arab Middle East is a closed system, in that demographic characteristics have not been influenced by large-scale outmigration. Almost all movement across national boundaries is within the region and usually of temporary duration. In this context, four types of migratory situations can be delineated, each differing according to manpower composition and attendant implications:

1. Countries that export largely skilled or professional labor (Egypt most notab1y, as well as Lebanon and Jordan);

2. Countries that import a large or critical portion of the labor force, particularly skilled workers (Kuwait, Saudi Arabia, Libya, and the Arab states in the Gulf region);

3. Countries that export relatively unskilled workers (Algeria, predominent1y); and

4. Countries that are relatively "self-sufficient" and neither extensively export nor import labor (Tunisia, Morocco, Syria, and Iraq).

In addition, there has been some major movement of Palestinians within the region, and an inflow of Pakistanis and Iranians, primarily to the states in the Gulf area. 
In large part, regional flows are determined by individual responses to economic and social incentives, yet shaped by political constraints. Economic incentives, such as higher wages and greater employment opportunities, are modulated by social incentives such as better quality of life, greater access to social services, and better prospects for social mobility. The political constraints on migration include direct governmental controls encouraging or impeding movement as the case may be, the use of immigration laws as a foreign policy instrument, and the use of tax policies as means of encouraging (or hindering) labor mobility.

The new migration in the Middle East is dominated by the movement of Egyptians to other Arab countries motivated largely by economic incentives. Egypt has for long provided the technocracy of the Middle East, exporting professional manpower and, to some extent, relatively unskilled workers as we11. Egyptian teachers, engineers, lawyers, doctors and the like have migrated to other Arab countries in search of better opportunities. They have formed the backbone of the professional communities in Libya, Kuwait, Saudi Arabia and the other Arab states in the Gulf area. It is not the fact of Egyptian emigration that is nove1, but its extent, rate of increase, and role in the economies of the recipient countries.

The composition of Kuwait illustrates the pervasiveness of labor migration. In that country over half the total population is non-citizen and over $70 \%$ of the skilled or professional occupations are staffed by nonKuwaitis. If current trends persist Egyptians will constitute the second largest alien group. ${ }^{1}$ The Kuwaiti government has long been concerned with finding means of promoting national development without substantially changing the nature of the political community or the privileged position of its citizens - and the issue of migration is of high political salience. But this predicament is not that of Kuwait alone, it is typical of those Arab states where professional manpower is the single most scarce resource.

Egypt's position as a major donor to other Arab states is due to a particular mix of supply and demand relationships. On the supply side, three factors stand out. First is an extensive Egyptian infrastructure that produces a large number of university graduates every year. Second are the limited domestic opportunities for the employment of these graduates. And third is the resulting pool of employable manpower that is not 
absorbed by the internal workforce. These factors are reinforced by the social equity programs of the government and its commitment to the expansion of the country's educational base irrespective of employment opportunities.

On the demand side, the most important factors are the economic incentives in Arab states that have provided the traditional motivations for immigration. These were reinforced by the petroleum crisis of October 1973, with the attendant price increases and the generation of surplus revenue which provided greater impetus for the migration of Egyptians to the oilrich states. The formulation, often hasty, of elaborate development programs that called for mass reliance of imported labor provided a clear economic rationale for immigration.

The new demand for Egyptian manpower is reinforced further by the long standing role of Egyptians as mediators between Western technology and Arab requirements. A two-step flow of technology transfer in the Middle East has evolved during the past twenty years, channelling flows from the industrial states to Egypt, and from Egypt to the other Arab countries. The brokerage role of Egyptians in technological transfers was reinforced once more by the increased demand for Western technology in the oil-rich states following the rise in petroleum prices.

In addition, some non-economic factors affect the demand for Egyptian labor. In the area of manpower, Egypt's advantage lies in the cultural similarity that reduces the difficulties of accommodation and adaptation to an alien environment. Although other Arab states import labor from elsewhere, most notably Iran, Pakistan, and India, Egyptian labor is clearly more desirable. So, too, the country's traditional role of political leadership in the Middle East is undoubtedly an important sociological consideration contributing to the demand for Egyptian labor. Egypt has long set the lines of regional policy, shaping ideological debates and serving as the hub of communication throughout the Arab world. Closely related is Egypt's position as cultural pace setter in the region, serving the educational requirements of other Arab states through expanded enrollments in Al Azhar, the religious university, and in Cairo University to accommodate more Arab students. The formal adoption of an Arab identity, promulgated officially in the 1956 constitution following the revolution, 
reinforced Egypt's role as cultural and political leader in the region, strengthened the incentives for enhancing its service role vis-a-vis the other Arab states and increased the latter's demand for Egyptian labor.

But the flow of manpower is only partly determined by the supply of Egyptians and the demand in other Arab states. Migration has become, for both donor and recipient, an indirect and often inadvertent instrument of foreign policy. Regional politics and migration patterns are inextricably intertwined. Times of poor relations among the Arabs were reflected in the decline of migration; occasional inter-Arab détentes accelerated the flows. For example, the large-scale migration of Egyptians to Libya during 19691973 coincided with the period of closest Libyan-Egyptian economic and political collaboration. Since 1973 the issue of migrant workers has been used for political leverage by both Egypt and Libya. In the summer of 1975, Libya threatened to expel some Egyptians and cancelled the work permits of numerous teachers. The issue had become explosive and the Egyptian grievance against the Libyan action featured prominently in Cairo newspapers. In Egypt it was feared that the Libyan move signalled the beginning of large-scale expulsion of Egyptians. At the same time, however, most Egyptien officials considered that possibility remote, given the importance of Egyptian manpower to the Libyan economy. By the same token, an implicit Egyptian move not to permit any further migration to Libya was regarded as a threat in Libya and, possibly, the same calculations have been made. While this incident did not lead the two countries to the brink of war, it severely strained their relations, adding further fuel to an already tenuous situation. In short, the Libyan episode reflects the importance of political factors influencing migration and the potential use of population movement as a political threat. In the Middle East, political objectives and priorities have for long shaped economic policies. Should migration continue to be viewed as a political weapon, the volume of Egyptian workers in Arab countries could become one of the most salient foreign policy issues in the years to come.

III. Egyptian Policies and Migration Patterns

Egyptians have always been close to their land. The fellah is renowned 
for his refusal to leave Egypt. Alternative schemes for the exportation of peasants were never a success. Proposals to employ Egyptian labor for cultivating the Gezira region of the Sudan (during the period of AngloEgyptian control of the Sudan and, intermittently, throughout the early years of the revolutionary regime) and plans to export fellahs to syria (during the brief union, 1958-1961) were notable failures. Incentives proposed were clearly inadequate, and traditional values could not be shaken.

The common consensus is that Egypt has not experienced any sizable inmigration nor out-migration until the most recent years. The number of foreigners residing in Egypt as recorded in the 1897 census was 112,000 . By 1960 census figures reflected a marginal increase to $143,000 .^{2}$ The number of Egyptian nationals living abroad was similarly few. Following the nationalizations of the Nasser regime, Greeks, Italians, Armenians, Jews, and Egyptians affiliated with the ancien regime left Egypt. In 1965 it was estimated that less than 100,000 were recorded as migrants in that year. ${ }^{3}$ And most of these were working in Arab countries as teachers and professionals. 4

The revolutionary government established in 1952 had viewed migration as an instrument of internal political control. Domestic repression was accompanied by stringent immigration laws. Obtaining an "exit visa" proved to be one of the most difficult attainments of any Egyptian seeking to leave the country. Strong currency controls were instituted in an effort to reduce the outflow of capital. And those familiar with Egyptian internal politics came to view changes in immigration regulations as a reliable barometer of domestic tensions. The most severe strains in domestic politics were between 1961 (the break-up of the union with Syria) and 1967 (the third war with Israel).

The government's policy in controlling migration to the West was to reduce dependence on the United States, Great Britain, and France, and to signal greater rapprochement with the Soviet Union and the Communist countries. Migration to the Arab states was also affected by this policy. On the other hand, the other Arab states' suspicion of Nasser's political motives was reflected in a reluctance to encourage the emigration of Egyptians. 
The Sadat regime liberalized domestic politics and, following the 1973 war, proclaimed an "open door" policy. To the Egyptians it signified not only the possibilities of foreign investment in Egypt, but prospects for Egyptian migration abroad. In contrast to emigration restrictions in earlier years, the new Sadat migration policy had become singularly "open."

The fundamental changes in regional politics, characterized by a movement from ideological politics to pragmatic stances and by Egypt's willingness to relinquish a position of dominance in the Arab world, contributed to the reduction in inter-Arab hostilities. ${ }^{5}$ In effect, Sadat had argued for an appreciation of the new leverages associated with oil revenues and recognized the consequences of alienating the oil-rich states by pursuing the old Nasser strategy of Egyptian dominance. By accepting, even arguing for, a reduced role in Arab politics, Sadat allayed his neighbors' suspicions and, more important, indirectly reaffirmed Egypt's cultural and political importance to the other states in the region.

This shift in real politik has had significant effects upon patterns of migration throughout the region. The demand of other Arab states for skilled manpower could now be met by the outflow of Egyptians without immediate political obstacles being interposed. In short, while the increase in petroleum prices and attendant growth in surplus revenues of the oil-rich states resulted in an immediate growth in demand for skilled Egyptians, the ability of the Sadat government to convince neighboring Arab states of its benign political intents was undoubtedly the most important factor directly responsible for increased migration.

But Egypt has had no concerted migration policy. At most there have been only a series of measures that have indicated the government's willingness to permit emigration. Abolition of the "exit visa" requirements was of great symbolic significance and its practical effects were extensive. Now the decision to migrate has become entirely a matter of individual discretion; there are few political obstacles. In fact, completion of the mandatory military service is the only remaining restriction.

Despite these changes the migration of Egyptians to the other states has never been of great concern to the new government. At most it has been viewed as an indication of good will and a reflection of domestic political 
liberalization. Nor has there been an appreciation of either the economic or political implications of this migration or of its effects. Even the total number involved has not been clear. Yet measures are being taken that have profound consequences for patterns of migration and have contributed to an acceleration that became noticeable in day-to-day life among educated citizens in urban areas.

Among these immigration-related measures three stand out. First are the new import regulations, such as the "own exchange" policy established by decree in 1974 that allow Egyptians to import consumption and capital goods with foreign exchange from earnings abroad and absolve any license requirements up to L.E. 5000 through the intermediary of the Central Bank. Because of foreign exchange scarcities, this system has become an important incentive to migrate in order to remit portions of earnings in this manner.

Secondly, the government is currently engaged in surveying the Arab countries' requirements for manpower and "matching" these from Egyptian sources. Recent talk of developing vocational programs aimed at Arab markets is indicative of this new orientation.

Thirdly, brokerage agencies have been created for mobilizing and channelling Egyptian migrant outflows. ${ }^{6}$ These agencies operate not only as facilitators for migration but as active agents for influencing individual decisions to migrate. Although these firms were largely private, recently there appears to be direct government participation.

These measures have affected not only the migration of skilled manpower, the most visible migrants, but unskilled labor as well. Increasingly doubt has been cast on the myth of the sedentary Egyptian. The view of the fellah close to the land can also be disputed. A two-step flow is becoming apparent. In addition to movement from urban areas to other Arab lands, rural areas are also becoming sources of recruitment, with flows first to urban areas, then abroad. ${ }^{7}$

Incentives for migration are now different than the past. Government approval and the development of institutional facilitators has helped destroy previous views of migration. A new conventional wisdom is required to explain sharp changes in behavior. Certainly, an approving government and 
a supporting environment shaped these changes. But it remains unclear whether the new incentives have resulted in long-term changes or whether they reflect short-term, pragmatic accommodation to current conditions.

\section{Characteristic Features}

Any assessment of the gains and losses to Egypt -- and to the region as a whole -- of increased migration to other Arab countries is contingent upon at least four factors.

1. Total numbers involved and proportion in other Arab states;

2. Duration of migration;

3. Level of knowledge and skills of migrants and their earnings;

4. Government control policies to channel migrants and their remittances.

Total numbers:

In the past, Egyptians who moved to other Arab lands went largely to Libya and to the Sudan. They were mostly unskilled and represented only a small and unimportant fraction of the labor force. Geographical continuity coupled with periodic political schemes at unification of the Nile Valley and the immediate surroundings fueled such movements. But they were largely erratic. There were also skilled Egyptians working in the Arab Peninsula and the Gulf region for many years, but again, the numbers have been small until recently. For example, in 1965 the census of Kuwait reports 11,021 Egyptians as compared to 500,000 Kuwaitis. Five years later, census figures reported a near trebling of the number of the Egyptian population to 30,421 , almost doubling the percentage of Egyptians to the total Kuwait population. But, still the numbers involved were quite small -- both relative to Egypt's total labor force and, most pertinently, to that of Kuwait.

The 1967 war had undoubtedly contributed to the growth of migration -and to the outflow of skilled manpower -- and the 1970 census reflects this contribution. The closing of the Suez Canal and the devastation of Suez City and Ismailia resulted in large-scale uprooting, estimated at several 
hundred thousand Egyptians, most of whom poured into Cairo. This movement, in turn, may have led to the search for employment opportunities in other Arab countries by a group of people that had already been uprooted and were therefore more likely to move again, this time with the assurance of employment and personal security.

It was not until the war of 1973 that a marked and accelerated increase in Egyptian migration took place. Although precise figures are not available from Egyptian sources, educated guesses of total migrants range from 225,000 to $500,000,{ }^{8}$ and possibly as high as one million or $10 \%$ of Egypt's total labor force. It is also estimated that the largest numbers went to Libya, Kuwait, Saudi Arabia, and the other Arab Peninsula states, in that order. But, given the paucity of systematic information, it is difficult to evaluate the reliability of such guesses.

Despite these uncertainties, some fundamental changes in the direction of flow have become apparent. First, Egyptians have been moving beyond the traditional host countries on their borders, Libya and the Sudan. They are now migrating in greater numbers to Kuwait and Saudi Arabia. Distance and lack of familiarity do not constitute sufficient psychological or political constraints on migration. Second, a two-tiered flow has been developing, of Egyptians going to Saudi Arabia and Kuwait, and Saudis and Kuwaitis moving to the smaller Arab oil states. Saudis and Kuwaitis in the other Gulf states performed essentially the same functions that Egyptians did in Kuwait and Saudi Arabia. In addition, cultural affinity and familiarity with the Gulf region provided added incentives for such movement. Third, this Gulf flow may even be pre-empted by the direct movement of Egyptians to Qatar, Bahrein, and Abu Dhabi. The post-1973 expansion of opportunities in the smaller Gulf states created a new demand for Egyptians, and the Egyptians were willing and able to meet this demand.

\section{Duration:}

In the past, Egyptians moved for short periods. Work permits and contracts often specified termination dates. Countries of destination seemed to encourage the temporary nature of the migration and, in some cases, placed specific obstacles to permanent residence. For example, Kuwait has stringent requirements for obtaining an entrance visa and 
establishing residence, and even more stringent ones for citizenship. It remains unclear at the present time whether the recent wave of Egyptian migration will be of a longer term or permanent nature. Existing rules and regulations are such that they reinforce short durations. Should these change, it is likely to be largely in response to economic pressures in Arab states, not to political pressure exerted by the government of Egypt.

Level of ski11:

Despite the small numbers that were involved prior to 1973, Egyptian manpower has comprised the backbone of the educated personnel in the Arab countries of the Gulf area. In addition to the continuation of these trends, unskilled workers have also been migrating to the Gulf. And the patterns that seemed to prevail for Libya and the Sudan alone were extended to other regions as well. To the extent that such flows persist they might well constitute a net drain on Egyptian manpower resources at some levels, one that may impact upon the skilled and perhaps the unskilled components of the labor force.

\section{Control policies:}

At the present time, Egypt has no official migration policy. In effect the government is promotional in its orientation and even implicitly encouraging. But the determination of movement is still one of private initiative. Lifting government restrictions caused a marked increase in migration. Such an increase may well accelerate if the government adopts interventions that are explicitly designed to encourage inter-Arab migration.

Discernable migration-controlling policies may soon come from the recipient countries. The posture of the Arab states has been one of dependence upon the Egyptians coupled with caution at times bordering on suspicicr, if not hostility. Kuwait, for example, has effectively segregated its citizens from the alien population, and it has developed an intricate system of regulations to safeguard this segregation. That situation of dependence-yet-reluctance has defined the country's population "problem" and resulted in the development of plans to replace alien workers in the long run with Kuwaiti citizens. " To the extent that immediate "solutions" lie in separating the alien workforce and prevent its effective integration 
into the body politic, a two-class system will be consolidated, leaving the migrant Egyptians essentially politically disadvantaged in their host countries.

The interactive effects of numbers, duration, skills, and government policies will, in the last analysis, shape the evolution of the migration situation in the Middle East. What the other Arab states will do will inevitably affect the Egyptians. Similarly, Egyptian policies may well have reverberating effects. In the short term, however, it is possible to identify some benefits and costs to Egypt of maintaining prevailing patterns of inter-state migration.

\section{v. Benefits to Egypt}

Calculating the benefits of migration is not an easy task, not only because of the uncertainties about total number involved, but because the social, political, and economic gains are neither clearly additive, nor are they obviously multiplicative. Indeed, the functional relations among various benefits are themselves an area of marked uncertainty. Nonetheless, an enumeration of the type of benefits that accrue from migration is one step in that direction.

\section{Socio-political benefits:}

1. Increased migration of both skilled and unskilled workers may well decrease the load on already accelerating demands for employment. The government's traditional responses to these demands have been twofold. One, expanding employment opportunities in the public sector; and two, creating "posts" in the sense of bureaucratic adjustments to employment demands. At one point, a ceiling had been imposed on the number of skilled jobs an individual worker may hold at one time. Since the liberalization of the Sadat regime, this regulation has been lifted.

2. Migration may reduce the probabilities of mobilizing social discontent and political opposition to the government. The educated intelligentsia that had been shaped by the revolutionary government's commitment to expand education opportunities has always served as a potential 
reservoir of political opposition. University graduates are among the most mobilizable sectors of the society and have, periodically, exerted that potential. Organized labor has intermittently opposed government employment and wage policies, but since strikes are illegal, there has been a built-in constraint on the effective mobilization of workers. Allowing, and even encouraging, migration of the relatively unskilled also serves to reduce the more popular domestic base from which political opposition might potentially evolve. Although this effect may be of negligible significance, it does bear upon the government's popularity and the extent of mass support.

3. As a consequence of the above, since, in Egypt, portions of both university graduates and unskilled labor tend to share an ethos of radical fundamentalism, the domestic political effects of the migration of potentially dissatisfied elements might have greater than proportional benefits for domestic stability.

4. Diffusion of Egyptians in other Arab lands might serve to reduce perennial suspicion of Egyptian political motives, potentially create a common labor force, and enhance inter-Arab communication. This effect is related to the cultural consequences of migration.

\section{Socio-cultural benefits:}

5. Increased migration may enhance the role of Egypt as the pace and taste setter of the Arab world and reinforce its dominant cultural position in the region (particularly given the immobilization of Lebanon and the neutralization of Lebanese competition with Egypt for cultural dominance). Increasing Egypt's cultural role is a benefit because it would enhance the desirability of Egyptians in the other Arab countries and provide an added rationale for importing Egyptian rather than other skilled individuals.

6. As a result, this cultural effect may have economic effects as well. For example, exports of Egyptian cultural goods to other Arab countries has been noticeably increasing over the past several years. ${ }^{10}$ Exports of films, books, magazines, and newspapers have always been extensive, by far greater than the closest competitor, Lebanon. In turn, the expansion of the Egyptian film industry during the past ten years has reinforced the country's cultural role in the Arab world. 
7. The cultural and political effects of such exports are likely to be considerably greater than the direct economic ones since these constitute a small fraction of total exports. ${ }^{11}$ However, there may be indirect effects. With increased migration of Egyptians to Arab countries, the demand for such exports will grow and external investments in these industries might also increase.

\section{Economic benefits:}

8. Remittances of Egyptians working in other Arab countries appear to constitute a potentially important economic benefit. Its actual effects will depend on the extent to which migrants remit fractions of their savings, and the extent to which the Egyptian governments capture these remittances. Remittances have been estimated at $\$ 400$ million to $\$ 800$ million annually. ${ }^{12}$ Government figures placed remittances at L.E. 157.5 million in 1976, a considerable increase from L.E. 41.5 million in 1973, and L.E. 85.4 million in $1974 .^{13}$ These figures are likely to be underestimates, given difficulties in accounting procedures and in distinguishing foreign capital inflows from immigrant remittances. Although remittances are marginal compared to GNP, they are large compared to the current account deficit in the balance of payments. Covering that deficit is the major economic contribution of remittances.

9. The "own exchange" system noted above will affect remittances. 14 Further, all imports under that system are taxed and at high rates for luxury goods. At one point, the duty on automobiles was at $100 \%$ of purchase price. The establishment of Arab banks in Egypt and expansion of Egyptian banking services to enable nationals to hold accounts in foreign currencies may, in turn, encourage remittances.

10. Increased migration of skilled and unskilled labor may lead to shortages of domestic manpower for local use. This shortage will result in increased wages due to the scarcity of labor, thus directly benefitting the individual worker.

11. Government measures to encourage individual imports and remittances stem from the new "open door" policies and attendant political liberalization. One consequence may be strengthening public confidence in the government. 
Such confidence may also increase prospects of remittances and of domestic investment in Egypt. This may initially affect only small businessmen ani small scale industries, but it may considerably improve the broad political "atmosphere" related to economic issues.

VI. Costs to Egypt

The costs of migration can largely be viewed in economic and sociopolitical terms.

\section{Economic costs:}

1. The migration of skilled workers and educated manpower who would otherwise be, or become, employed represents a loss for the country by depriving the society of the gains associated with the use of skilled manpower, and more specifically, by depriving it of the returns from investment in education. This is the direct cost of "brain drain" in Egypt. The brain drain effect is most pronounced in certain sectors such as medicine and higher education.

2. The costs of educating the labor force may increase if migration creates incentives for more people to enter such institutions. Similarly, the costs of training unskilled labor will increase with incentives which encourage more workers to migrate after obtaining vocational training or on-the-job experience on location in Egypt.

3. Since the government seeks to capture remittances, increased migration will entail greater costs for the establishment of machinery to capture remittances.

4. Increased wage differentials between Egypt and other Arab wage scales, increased use of the "own exchange" system, and increased remittances through official and unofficial channels may adversely affect the distribution of income in Egypt. ${ }^{15}$ Educated guesses place Arab wages at 5-10 times their Egyptian equivalent. Thus emigration creates a class of recipients substantially above the Egyptian averages.

5. Uncaptured remittances that go to consumption can create socially 
visible evidence of income differences and of accentuating income inequalities. In inducing emulation, they place added burdens on government economic policies by creating an interest group that demands imports of luxury and other goods. These interests may be translated into a social cost by preventing the government from pursuing economic policies that may restrain the expansion of consumption habits.

6. Since remittances are not subject to Egyptian taxes, government tax revenue is appropriately curtailed, possibly as compared to the taxed income of emigrants had they remained at home. This factor, in conjunction with the effects of the "own exchange" system may, on balance, constrain government efforts to control both the flow and its utilization.

7. The combined effect of the above is to extend existing consumption patterns and activate new habits, thereby constraining that fraction of savings from income earned abroad that could potentially go into investments in Egypt.

8. Increased reliance on skilled Egyptians results in greater concern by other Arab states to educate their own citizens. Since Egypt has long been the cultural center of the Middle East and Egyptian educational institutions service the entire region at Egypt's own expense, a greater inflow of other Arab students will create an added cost of educating the citizens of neighboring countries.

\section{Socio-political costs:}

9. The migration of professional and skilled workers may reduce that fraction of the educated population that has an effective stake in the development of the domestic political process. The educated population constitutes an important, if not necessary, component of any coalition supportive of government policies. In a country where education is at once a status symbol and a resource, the interests of the educated are critical to domestic political calculations.

10. Increased Egyptian migration to Arab countries may mobilize nationalist reactions in the communities of destination. Officially the Arab countries are anticipating an eventual replacement of migrant workers while, at the same time, planning for increasing their immediate dependence 
on imported labor. A visible growth in the Egyptian component of the Arab labor force may accelerate the Arab government's control of migration and consolidate existing rules for regulating and eventually reversing the flows with consequent adjustment problems of returnees.

11. Such a nationalist reaction could be translated into charges of Egyptian imperialism. Any allegations of this sort will have detrimental effects on these countries' political relations. For example, they will increase the sensitivity of the Arab League to charges of domination by Egypt, and the other Arab governments' sensitivity to influence of the Sadat regime.

12. Less immediate, but no less plausible, is the possibility that Egypt's political credit with the other Arab governments may be so damaged by the existence of a large and activist Egyptian migrant population as to affect other issues and other dimensions of inter-Arab politics. If migration does not directly create the damage, it will certainly accentuate prevailing tensions. Should such development occur, the advances made in Arab integration since the 1973 war could be effectively eradicated, and with it possibl: the new concillatory posture on regional issues.

This list of gains and losses is only an enumeration of the types of consequences associated with migration. No note is taken of potential trade-offs, or net effects, or of interactive consequences. In addition, what might be viewed as gains (or losses) in the short term may result in losses (or gains) in the longer run. Inter-temporal effects are also not taken account of. And although the listing of costs and benefits differentiates between political and economic effects, it does not address the possibilities of trade-offs across types of effects.

\section{Migration and Development Planning}

The evidence is ambiguous about the number of development plans that have been formulated in Egypt since the revolution. 16 This is at least partly due to the confusion over economic planning generated by uncertainties arising out of periodic wars with Israel. At least four sets of comprehensive plans have been formulated since Egypt adopted planning as 
an instrument for defining economic priorities and development objectives. 1

$\begin{array}{ll}\text { First Five-Year Plan } & 1960 / 61-1964 / 65 \\ \text { Second Five-Year Plan } & 1965 / 66-1969 / 70 \\ \text { Emergency Three-Year Plan } & 1967 / 68-1969 / 70 \\ \text { National Action Program } & 1973-1982, \text { including } \\ \text { (a) The Third Five-Year P1an, } 1973-77 \\ \text { (b) The Fourth Five-Year Plan, 1976-80 }\end{array}$

The characteristics of the First Five-Year Plan are we11 documented. It was the first part of a broad ten-year program extending to 1970 . The second part, the Second Five-Year Plan, was scheduled to begin on July 1 , 1965. At this point, information on the evolution of Egyptian plans and planning in general becomes ambiguous. According to one Egyptian source, 18 the results of the First Five-Year Plan led to a decision to replace the Second Five-Year Plan with a new, more ambitious Seven-Year Plan. The former was never implemented; the latter was never formulated. Only sketchy information exists on broad social and economic objectives. Apparently the rationale in government circles for abandoning the second plan was that the economy was in need of a "breathing space" to consolidate itself. 19

In 1967 a new Emergency Three-Year Plan for the period 1967/68-1969/70 was introduced. The war of 1967 intervened and generated a new situation. National objectives were revised to accommodate defense expenditures that accounted for more than $30 \%$ of the country's GNP during that year. Shortly after its announcement the Plan was put aside entirely. 20

In mid-1972 the government announcedits intent to begin a new tenyear plan, the National Action Program, beginning 1973 through 1982. That period was to comprise two five-year plans. In 1975 the first period plans were cut short, and a new plan from 1976 to 1980 was announced. The availability of information on various plans reflects the government's orientation and the importance assigned not only to the exercise but to the formulation of objectives.

The National Action Program represents the Sadat government's respecification of Egypt's objectives and reversal of the goals specified in Nasser's National Charter of 1962. The Charter was Egypt's first attempt to formulate nationwide developmental objectives. Although national goals 
were stated in broad terms often mutually conflicting and self-contradictory, the charter was an important political document outlining Egypt's new national orientation. It also gave rise to the first efforts at comprehensive planning. Officially, the Nasser goals persisted until his death. The October. Paper of Sadat represented the new government's respecification of national objectives and its announcement of domestic liberalization.

Neither the two sets of directives nor the intervening plans recognized or analyzed the country's population characteristics or the migration of skilled labor. For example, the First Five-Year Plan simply assigned a target of $17 \%$ increase of employment over the Plan years, but it did so irrespective of information on rural/urban migration, fertility rates, or on inter-state movement. The Plan was not based on or informed by systematic demographic analysis. Analogous omissions are apparent in subsequent planning documents. In addition, aside from an isolated recognition of the potential importance of Egypt's manpower as a national resource, ${ }^{21}$ Egypt's workers abroad have also been essentially ignored.

By contrast, for countries receiving Egyptian labor, the issue of migration plays a central role in development plans and programs. Even prior to the increase in oil prices in October 1973, these countries had placed strong emphasis on migration-related policies. For example, the First Five-Year P1an of Kuwait (1967/68-1971/72) stressed the need for the regulation of migrant workers and for the development of guidelines covering general populations issues 22 -- thus legitimizing the government's concern for the political and economic implications of continued reliance on migrant workers. Of the eleven goals specified in the plan, four were concerned directly with population and migration issues:

1. Increasing the Kuwaiti population to a majority status;

2. Assuring a Kuwaiti majority in the labor force;

3. Creating employment opportunities and expanding the size of the citizen labor force;

4. Restricting the use of migrant labor, except in highly skilled and technical vocations, to be balanced by the exit of equivalent numbers of unskilled foreign workers. 
At the same time, official Kuwaiti government policy was to provide incentives for its young citizens to study abroad so as to, eventually, constitute that required Kuwaiti majority in professional vocations. Since the end of the first Plan period, the government has regulated further the flow of skilled manpower. As long as Kuwaiti salary scales are several times that of other Arab states, as long as the government seeks to collaborate economically and politically with its neighbors, and as long as they try to grow faster economically than their own population increase will permit, a policy of eliminating net inflow of migrant workers is unlikely. Partial restrictions may well evolve, and these may be specific by country of origin. But so far, the restrictive policies have not been of this kind.

Planners in Kuwait are intuitively aware of the socio-economic and political implications of the demographic structure of the country and good statistics are kept, yet there is an insufficient appreciation of the effects of restrictive or, alternatively, expansionary migration policies, in general and by sector. Despite the country's regional orientation, and its avowed commitment of resources for Arab development, ${ }^{23}$ the contradiction between that purpose and the restriction of Arab workers is not fully appreciated. The persistence of conflicting objectives, such as rapid economic development and manpower self-sufficiency, highlights even further the problems generated by alien workers in Kuwait. As noted earlier, the Kuwaiti predicament is shared by other Arab countries that depend upon citizens of other countries for their professional manpower. The mutual interdependencies among Arab countries are only dimly recognized. And there is little appreciation of the costs and benefits of migration or of the use of foreign labor for common gain.

VIII. Toward a New Exchange: Some Policy Options

Calculating the implications of migration for Egypt alone is distinct from, but closely related to, the recent increase of in-migration of Arabs into Egypt. This two-way flow, in turn, is an intrinsic consequence of the new Sadat policy of greater cooperation with the other Arab states. This policy provides the context for any Egyptian concern for developing a more rationalized approach to migration. 
When viewed in this context, several issues are particularly illustrative of Egypt's predicament with respect to migration policy. For example, as noted earlier, the education of Egyptian emigrants is in itself a major load on the government. Their migration to other Arab countries constitutes an immediate economic gain to the community of destination. The Egyptian government has followed a policy of expanding individual education opportunities in Egypt without commensurate investments in educational institutions. This policy has resulted in an ever-increasing burden on facilities already strained.

The persistence of this pattern of migration as it burdens the educational system inevitably contributes to the deterioration of higher education in Egypt. This deterioration will, in turn, result in the loss of a position of comparative advantage. ${ }^{24}$ Because of a political reluctance to discriminate between Egyptians and other Arabs either in admission or in tuition, the burden of added students has not been offset by any discernable economic gain. Recent attempts to raise tuition for Arab students have been piecemeal and marginal at best. If present patterns persist, in the long run the other Arab states themselves may be contributing to an eventual loss of Egypt's position of cultural dominance.

The increased flow of citizens from other Arab countries into Egypt is also traced to the October war and the rise in oil prices. This Arab migration is motivated not by narrow economic incentives or by prospects of higher wages, but by opportunities for more varied consumption and access to cultural, social, and other opportunities.

The apparent effect of this inflow is a demonstrable overload on the system in terms of social services, available amenities, distortions of prices and wages, and effective interventions in the composition of the domestic (non-migrant) labor force. ${ }^{25}$ There are no constraints on Arab movement to Egypt nor on location, residence, or duration of stay.

Raising the issue of the effects for Egypt of the conjunction of migration of manpower to other Arab countries and the flow of Arabs to Egypt inevitably bears upon the question of inter-Arab cohesion and creates political constraints on any economic calculations of costs and benefits of migration. Indeed, in that dual flow, politics tend to dominate other issues in shaping eventual government response -- or lack thereof. 
Inter-Arab cohesion has been at the forefront of Egyptian international policy since World War II, but the Sadat regime has placed added emphasis on regional harmony and on increasing collaboration with the Arab states on a variety of issues. The most obvious payoff to that policy lies in economic assistance from other Arab countries to Egypt, an assistance conceived -- and extended-- exclusively in terms of foreign aid. The country's dependence on Arab grants, loans, remittances, and outright gifts to meet its foreign exchange requirements adds a strong economic rationale for protecting interArab cohesion.

The role of the other Arab states has been that of donor relating to Egypt as the perennial recipient. The political price to Egypt of this assistance has been the abandonment of both an expansionist policy and a posture of political domination of the Arab world. The exchange is one of foregoing political objectives for economic gain. And the trade-off has evolved exclusively as one between political objectives and economic ones -all within the idiom of donor-recipient relationship.

Egypt's migrants to other countries represent an important resource to be exploited by the Egyptian government because of their importance to the economies of the recipient countries. Although there is, as yet, no concerted policy of utilizing this resource for national development, that possibility remains alive. Of the policy options available to the Egyptian government for capturing the benefits of its migrant labor, four are particularly worthy of consideration.

First, is a policy of levying a tax on individual migrant earnings. This possibility has been suggested in various circles, but never seriously entertained either in the Middle East or elsewhere. The difficulties of raising and collecting such a tax are extensive given the problems of control, monitoring migrant earnings, and devising means of extraction. Furthermore, such a tax would produce the same macro-economic effects as capturing remittances. In the Middle East context, any effort to tax the individual migrants will be fraught with practical difficulties. So, too, it would mobilize a new interest group in opposition to government policies. A coalition of skilled and unskilled migrants would constitute a powerful obstacle to the effectiveness of such a policy. 
A second option is a bilateral state-based agreement which would entail an overall charge from the Egyptian government to recipient countries for the employment of Egyptian manpower. That charge would depend upon the composition of migration, its duration, the tax structure of the recipient country, and possibly the value of remittances.

A third policy option is to develop international rules and regulations for raising state-based contributions to manpower development on a regional basis, whereby all participating countries in the Middle East will become involved in devising the means and procedure of exchange.

A still fourth possibility is to develop a consortium of major interests (or parties) participating in the flow of manpower by industry and occupation and devising exchange policies that are agreed upon, and implemented, on a state level.

Options two, three, and four place the migration issue in an international context and seek to employ labor movements as the focal point of an overall exchange between Egypt and the Arab states. That exchange would be designed to enable each country to capitalize on its respective characteristics in the broad regional context. A key criterion for defining the nature of such an exchange, based on a state-to-state agreement, is the following: to find a procedure for channelling national resources to support services that benefit the region directly or indirectly without jeopardizing national objectives. The underlying principle is to tax human capital movement and to request physical capital flows to affect and/or maintain human capital flows.

A state-based levy -- in terms of bilateral, international, or consortium of sector interests-- would entail two principal features. First, an Egyptian state charge for the migration of labor (corrected appropriately for the direct economic gains to Egypt of this migration to avoid erroneous accounting) and, second, an Arab commitment to investments in those services located in Egypt that directly benefit the citizens of other Arab states. These two features are tied by the directive of searching for the prospects of mutual gain. In addition, the adoption of these two principles would enable Egypt to capture some of the benefits associated with the migration of labor without effectively reducing the individual incentives to migrate 
while at the same time, they would enable Egypt to channel investments in those internal sectors that are most directly affected by Arab migration and that, in turn, benefit the Arab communities most directly.

From the Egyptian point of view, the major incentive for such an exchange perspective-- as opposed to a policy taxing the earnings of individual migrants or a policy of ignoring the migranto- is to protect its position of labor advantage. The importance of Egyptian knowledge and skills in the area may be of short duration unless attendant institutions are expanded effectively. Unless that role is protected and utilized as a national resource its usefulness for developmental purposes will be short-lived.

From the perspective of the other Arab countries, the major incentive for such an exchange is the possibility of encouraging short- and long-term skill redistribution in the region. Planning for technological change may be facilitated with the assurance of orderly access to regional skills. Such an exchange will facilitate the ordered channelling of the existing two-step flow of the transfer of technology in the Middle East, from the advanced industrial states to Egypt, and from Egypt to other Arab countries.

An exchange policy predicated on the realization that the gains to the separate Arab states of the Middle East entails a movement for them all from a reality of dependence to one of acknowledged interdependence. Arab solidarity is predicated on the rhetoric of interdependence, yet, in fact, it has been demonstrated in terms of bilateral dependencies: Egypt's dependence on Arab economic assistance, and Arab dependence on Egyptian manpower. Placing this dual lependence in a framework of regional exchange would substantially affect the dominant idiom of inter-Arab relations and of the perception of Egypt as an ever-present drain on Arab resources. It would provide a political and economic rationale for mutual claims on national resources, the exchange of which would result in shared benefits.

The new migration in the Middle East is creating bargaining power for all states involved. How that power is used will have not only national implications, but regional implications as well. The extent 
to which Egypt shapes and maintains bargaining power -- either by arguing that the other Arab countries will gain by contributing to the development of Egypt's manpower resources, or by proposing to withhold its labor from other Arab states if common, mutual, and shared regional gains are not envisaged -- will, in turn, determine the broad lines of foreign policy and economic policies for the remaining years of the decade. 

NOTES:

1. The largest non-citizen group in Kuwait is composed of Jordanians and Palestinians. Kuwaiti authorities view these two groups as one given the composition of Jordan and difficulties in differentiating among Palestinian citizens of Jordan and Jordanian citizens. The census of 1970 lists Jordanians and Palestinians as comprising 20\% of the total population, an increase from the 16.6\% enumeration in the 1965 census. The next two groups are Iraqis and Iranians. The former constituted $5.5 \%$ of the population in 1965 , and decreased slightly to $5.3 \%$ by the 1970 record. The latter also decreased between 1965 and 1970, from 6.6 to 5.3. At the same time, the increase of Egyptians was from $2.4 \%$ to $4.1 \%$. This change, though smal1, was prior to the marked growth of migration to Kuwait following the 1973 war. The growth in Egyptian migration in conjunction with decline in Iraqi and Iranian migration is likely to place Egyptians in a more dominant position in Kuwait.

2. M. A. E1-Badry, "Trends in the Components of Population Growth in the Arab Countries of the Middle East: A Survey of Present Information," Demography (Vol. 2, 1965), p. 158.

3. A. Gritly, Population and Economic Resources in U.A.R. (Cairo, 1962), cited in E1-Badry, "Trends in the Components of Population Growth in the Arab Countries of the Middle East," 1965, p. 158.

4. Although this is a common view, iterated also by E1-Badry, there has been some employment of relatively unskilled labor in Libya.

5. For a survey and analysis of these changes see Nazli Choucri, Interiational Politics of Energy Interdependence: The Case of Petroleum (Lexington: D.C. Heath, Lexington Books, 1976), esp. Ch. 4. For comparative analysis of changes in inter-Arab conflicts see Ijaz Gilani, "The Politics of Integration and Disintegration: The Development of Pragmatic Arabism from Khartoum to Rabat (1967-74). A Study of InterArab Relations," (M.I.T.: Ph.D. dissertation for the Department of Political Science, in progress). 
6. There is little systematic information on the nature of these agencies, although presumably it would not be difficult to obtain some rudimentary data.

7. The nature and magnitude of this two-step flow is unclear. Its existence is based on prima facie evidence and on intermittent observation.

8. The Economist (November 13, 1976), p. 85 .

9. See Section VII below.

10. Based on statistics presented in the Statistical Abstract of Arab Republic of Egypt 1951/52 - 1971/72 (Cairo: Central Agency for Public Mobilization and Statistics, June 1973). See also Middle East and North Africa (London: Europa Publications, 1976).

11. The precise figures are difficult to come by. This inference is based on assessments in Richard Nyrop et.al, Area Handbook for Egypt (Washington: American University Foreign Area Studies, 1976).

12. The Economist (November 13, 1976), p. 85 .

13. The 1975 figure includes imports financed directly by Egyptians abroad in accordance with the "own exchange" system. For January-July 1976 the recorded figure is L.E. 61.6 million. Comparisons with 1973 and 1974 figures may thus be somewhat misleading.

14. Prior to 1974 only cash remittances were allowed. Government figures place the value of transactions under the "own exchange" system at L.E. 127,064 thousand or $\$ 317,660$ thousand (using the official exchange rate) from July 1974 to June 1976. The value increased almost tenfold from the first to the second six-month period. The three largest items under this system were engineering equipment, transportation equipment, and food stuffs. (Data obtained from unofficial memorandum prepared by the Ministry of Finance, October 1976). 
15. This possibility was pointed out by R. S. Eckaus.

16. The First and Second Five-Year Industrial Plans of the late 1950's are not included. The Second Five-Year Industrial Plan was inserted into the First Five-Year Plan, 1960/61-1964/65.

17. January 1973 Egypt adopted the calendar rather than the July-June fiscal year.

18. Rashad A1-Barawy, Economic Development in the U.A.R. (Cairo: Ang1oEgyptian Bookshop, 1970).

19. Robert Mabro, The Egyptian Economy: 1952-1972 (Oxford: Clarendon Press, 1974), p. 23 .

20. It has been observed that comprehensive planning "died in Egypt" at this juncture. Considerable work had been put into the plan, drawing upon Egypt's best economists and planners. Many left the country in the 1960's, resulting in a discontinuity of the learning process and leaving behind a marked gap in expertise and experience. The experience gained by the first team was essentially lost. See Mabro, The Egyptian Economy, 1974, p. 124. I am grateful to Richard Balfour for assistance in this survey of planning in Egypt.

21. A report prepared at the Institute of National Planning notes that: rich countries and rich regions within countries act as magnets attracting human resources, especially high level manpower, from poor countries and regions. These movements constitute a major form of subsidization of the rich areas by poor ones. This fact contributes to the wide and growing disparity between rich and poor countries and regions.

The outflow of talents from developing countries is -- in some cases -- countered by an inflow from developed countries in the form of technical assistance.

Final Report on Employment Problems (Cairo: Dar el Maaref, 1972), p. 27. But there is no reference to the possibility of exchange. 
22. Information available in the West on Kuwait's development programs is sketchy. The following observations draw upon Edmund Y. Asfour, "Prospects and Problems of Economic Development of Saudi Arabia, Kuwait, and the Gulf Principalities," in Charles A. Cooper and Sidney S. Alexander (eds.), Economic Development and Population Growth in the Middle East (New York: American Elsevier, 1972), pp. 385-387; Ragaei El Mallakh, Economic Development and Regional Cooperation: Kuwait (Chicago: University of Chicago Press, 1968), pp. 124-132; UN, United Nations Economic and Social Office in Beirut, "Plan Formulation and Development in Kuwait," in UN-UESOB, Studies on Selected Development Problems in Various Countries in the Middle East, 1968, pp. 11-24; Ragaei E1 Mallakh, "Planning in a Capital Surplus Economy: Kuwait," Land Economics (November 1966), pp. 425-440.

23. See Choucri, International Politics of Energy Interdependence (1976), Chapters 4,5 .

24. I am grateful to R. S. Eckaus for pointing this out.

25. The effects on money supply in Egypt are unclear, although there is some indirect evidence that there may be some impact.

26. Various proposals to "tax the brain drain" have been put forth. One of the most systematic efforts is Jagdish N. Bhagwati and Martin Partingon (eds.), Taxing the Brain Drain: A Proposal (Amsterdam: North Holland Publishing Company, 1976).

27. There have been recent reports of a Saudi Arabian contribution of possibly over $\$ 100$ million for building a new campus for Al Azhar University at Assiut. 